\title{
Language practices of the digital multi-semiotic genre meme by 3rd grade students in elementary school I
}

\author{
Práticas de linguagens do gênero digital multissemiótico meme por alunos do $3^{\circ}$ ano do ensino \\ fundamental I \\ Prácticas lingüísticas del meme de género multisemiótico digital por parte de alumnos de $3^{\circ}$ de \\ primaria I
}

Recebido: 28/09/2021 | Revisado: 04/10/2021 | Aceito: 06/10/2021 | Publicado: 12/10/2021

Michele de Paula Guimarães de Souza Pinheiro
ORCID: https://orcid.org/0000-0003-1747-1792
Universidade Federal do Pará, Brazil
E-mail: louro.mic@ gmail.com
Francisco Pereira Smith Júnior
ORCID: https://orcid.org/0000-0002-6336-9249
Universidade Federal do Pará, Brazil
E-mail: fransmithj@ gmail.com
Francisca Maria Carvalho
ORCID: https://orcid.org/0000-0002-3907-8732
Universidade Federal do Pará, Brazil
E-mail: carvalhof730@ gmail.com

\begin{abstract}
This article aims to discuss digital literacy in elementary school 1, considering the proposal of the Common National Curricular Base, particularly the linguistic/semiotic analysis. Specifically, to examine the generative path of meaning in the fundamental, narrative and discursive levels of the production of multisemiotic text, the meme, of 3rd grade students. Therefore, the question was asked whether 3rd grade students are being encouraged by the school to develop meaningful skills in the language practices of multisemiotic texts such as the digital genre meme. In response it is assumed that 3rd grade students, who can already be considered digital natives, comment on the content and even produce memes, because they are already being trained by the school to develop critical and reflective sense regarding the language practices of multisemiotic texts such as the meme. We adopted the axis of linguistic/semiotic analysis of the Common Curricular Base (2018), in the processes of reading and production of texts (oral, written, and multisemiotic), with Fiorin (2017), Soares (1998), and Ribeiro (2018) as theoretical support.
\end{abstract}

Keywords: Multisemiotic; Meme; Education.

\section{Resumo}

O presente artigo tem como objetivo discutir o letramento digital no ensino fundamental I, considerando a proposta da Base Nacional Comum Curricular, particularmente, a análise linguística/semiótica. Especificamente, examinar o percurso gerativo de sentido nos níveis fundamental, narrativo e discursivo da produção de texto multissemiótico, o meme, dos alunos do $3^{\circ}$ ano. Assim sendo, fez-se o questionamento se os alunos do $3^{\circ}$ ano do ensino fundamental I estão sendo estimulados pela escola para desenvolverem habilidades significativas nas práticas de linguagem de textos multissemióticos como o gênero digital meme. Em resposta pressupõe-se que os alunos do $3^{\circ}$ ano, que já podem ser considerados nativos digitais, comentam os conteúdos e até produzem memes, porque já estão sendo habilitados pela escola para desenvolver senso crítico e reflexivo referentes às práticas de linguagens de textos multissemióticos tais quais o meme. Adotou-se o eixo da análise linguística/semiótica da Base Comum Curricular (2018), nos processos de leitura e de produção de textos (orais, escritos e multissemióticos), tendo como aporte teórico Fiorin (2017), Soares (1998) e Ribeiro (2018).

Palavras-chave: Multissemiótico; Meme; Ensino.

\section{Resumen}

Este artículo tiene como objetivo discutir la alfabetización digital en la escuela primaria I, teniendo en cuenta la propuesta de la Base Curricular Nacional Común, en particular el análisis lingüístico/semiótico. Específicamente, examinar el camino generativo del significado en los niveles fundamental, narrativo y discursivo de la producción del texto multisemiótico, el meme, de los estudiantes de tercer grado. Por lo tanto, se hizo la pregunta si los estudiantes del 3er año de las escuelas primarias I están siendo estimulados por la escuela para desarrollar habilidades significativas en las prácticas lingüísticas de los textos multisemióticos como el género digital meme. Como respuesta se asume que los alumnos de $3^{\circ}$, que ya pueden considerarse nativos digitales, comentan los contenidos e incluso 
producen memes, porque ya están siendo formados por la escuela para desarrollar un sentido crítico y reflexivo respecto a las prácticas lingüísticas de los textos multisemióticos como el meme. Adoptamos el eje de análisis lingüístico/semiótico de la Base Curricular Común (2018), en los procesos de lectura y producción de textos (orales, escritos y multisemióticos), teniendo como aporte teórico a Fiorin (2017), Soares (1998) y Ribeiro (2018).

Palabras clave: Multisemiótica; Meme; Enseñanza.

\section{Introduction}

With the advancement of technology and easy access to the Internet, the use of social networks has been of great importance in today's society. From this we cannot deny that society is immersed in the globalized era of social media, in which information travels over virtual networks in real time. Therefore, it is believed that by working with the analysis and production of memes, the early years teacher will be contributing to the formation of citizenship. In this way, the school has a fundamental role in promoting the use of the most varied digital genres, in order to provide the student with a reflective vision about the infinity of media news that circulate daily in society.

Thus, the object of this research is the meme. The choice is based on the fact that this is a digital genre proposed by the Brazilian National Common Curricular Base (BNCC) during the reading and production of oral, written and multisemiotic texts; additionally, because it is popular in social networks. Kress (2003 apud Ribeiro, 2015, p. 114) states that "in both writing and reading, meaning is the result of semiotic work". For the author, people have little perception of the "semiotic power" of texts (such as images and sounds). For the BNCC, one of the specific competencies of Portuguese Language for Elementary School is

read, listen and produce oral, written and multisemiotic texts that circulate in different fields of action and media, with understanding, autonomy, fluency and criticality, in order to express and share information, experiences, ideas and feelings, and continue learning." (Brasil, 2018, p. 87).

From this perspective, the BNCC document suggests reading and writing practices in different textual and digital genres. We highlight digital genres, especially the meme, elected by the BNCC for its multisemiotic content. Given this, we raise the following question: are 3rd grade elementary school students developing significant skills in the language practices of multisemiotic texts?

\section{Literature Review}

For this research, we will use studies about digital literacy, gigital genres, digital genres, semiotic, and other teories. As Ferrari ${ }^{1}$ (2018 apud SEMIS, 2021) ${ }^{2}$, she "feels that the resistance to work with the topic is still great". For this reason, we assume that 3rd grade students use digital media since babies, comment on content and even produce memes, because they are already being enabled to develop critical and reflective positioning regarding reading and writing practices of multisemiotic texts such as the meme. Therefore, the main purpose of this study is to discuss digital literacy in Elementary I, considering the proposal of the Common National Curricular Base, especially linguistic/semiotic analysis. Specifically, to examine the generative path of meaning at the fundamental, narrative, and discursive levels of the production of a multisemiotic text, the meme, by 3 rd grade students. Additionally, to analyze the reading and production skills of multisemiotic texts with the digital genre meme by 3 rd grade students.

\footnotetext{
${ }^{1}$ Ferrari is professor of hypermedia and transmedia narratives at the Pontifical Catholic University (PUC-SP), researcher in digital communication and author of the book How to get out of the bubbles (Editora Armazém da Cultura. Source: https://novaescola.org.br/conteudo/12307/guia-de-letramento-midiatico-o-que-e-como-aplicar-e-identificar-desinformacao.

${ }^{2}$ https://novaescola.org.br/conteudo/12307/guia-de-letramento-midiatico-o-que-e-como-aplicar-e-identificar-desinformacao.
} 
Both the National Curricular Parameters (PCNs) and the Common National Curricular Base (BNCC) develop skills necessary for participation in language practices. These two documents converge with each other regarding the centralization of text and textual genres in a contextualized way, articulated to the social use of language. According to the BNCC:

The conception that supports the proposition of competencies and skills for the subject of Portuguese Language, on the issue of language(gem), privileges the enunciative-discursive approach, which provides for the interactions between language(gem) and subject as constituents for consolidation of (social) exchanges that take place through human action: "it is assumed here the enunciative-discursive perspective of language, already assumed in other documents, such as the National Curriculum Parameters (PCN). (Brasil, 2018, p. 67).

These two guidelines orient learning methodologies from discursive genres and their production contexts in order to develop written and oral practices, reflecting on language through linguistic analysis practices.

Both documents present the work with multiple languages, aiming to create contexts in which language practices can be meaningful, contemplating and establishing dialogical relations that allow the construction of knowledge and the development of skills. Moreover, they propose to subsidize the school with contents, skills and objectives, allowing students to have experiences that contribute to the understanding of multi-literacies that circulate socially in various textual and digital multimedia and multisemiotic genres, in order to make them critical subjects in various social contexts integrated in language practices articulated among themselves in the different pedagogical activities.

According to the PCNs (Brazil, 1997), language is realized in use, in social practices, in which the individual needs to expand his ability to use the language and acquire others he has not yet mastered, expanding his repertoire, the interaction with cultures, languages and diverse language uses in the different social spheres in which he is inserted.

These skills to be developed for the social use of language are related to language practices, organized around two basic axes: the use of oral and written language, and the analysis and reflection on language.

In the BNCC, the skills appear integrated and articulated with each other, associated with language practices, structured around the following axes: speaking, reading/listening, production (written and multisemiotic) and linguistic/semiotic analysis. The BNCC seeks to contemplate the new literacies, available in new genres and texts that are increasingly multisemiotic and multimedia, of multiple languages, essentially the digital ones that circulate in social networks and virtual environments such as the gif, meme, fanfic, various vlogs, parodies of different types, etc.

Understanding a lecture is important, as is being able to attribute different meanings to a gif or meme. Just as doing proper oral communication and knowing how to produce meaningful gifs and memes can also be. (Brazil, 2018, p. 69).

In order to reconstruct and reflect on the different genres that circulate in different media and fields of human activity, providing, to students, experiences that contribute to the expansion of literacies, in order to enable meaningful and critical participation in various social situations constituted by language practices.

\section{1 digital literacy}

According to Soares (1998, p. 04), literacy is the "result of the action of teaching or learning to read and write, the state or condition that a social group or an individual acquires as a consequence of having appropriated the writing", that is, a literate individual is one who dominates the use of reading and writing with effective participation, acting with full cognitive competence in various contexts of existing communication. 
According to Ribeiro and Freitas (2012, p. 64): "In digital literacy, appropriation is related to both the technique and the social use of reading and writing practices present in the computer-internet", that is, digital literacy does not mean only teaching how to use new digital tools, but also being able to interpret reading situations in the technological environment in a critical way.

To think of digital literacies as a cultural, social, and historical practice of socially organized groups is to go beyond their understanding as technical skills. It is to think about the social relations established between people involved in a given context of reading and writing use. ${ }^{3}$

Therefore, considering that, nowadays, we spend much of our time connected, our communication has holistically become more digital than personal, in which case, we cannot be passive to digital resources, but rather interact through them in an active, constructive and conscious way in different digital and social contexts.

\subsection{Digital Genres}

Marcuschi and Xavier (2005) define digital genres as new textual genres on the rise on the Internet. Such genres have particularities that aggregate, simultaneously, new languages such as texts, sounds, and images, with several meanings and senses present in virtual spaces.

Thus, with the advance of technology and the popularization of the Internet, new genres have emerged and others have undergone significant transformations in social relations in an instantaneous way, called digital genres. Therefore, the new language practices and their new characteristics have caused a great impact on digital communication as corroborates Blaszkowski (2019, p. 38):

with the emergence of digital technologies and network culture [...] individuals began to communicate in diverse ways, through sound, text, and image. In this environment, verbal language is no longer the main form of communication used. Based on this reality, digital genres are emerging, which are focused on the approach of the language used in technological media.

Therefore, it is necessary to work in the classroom through digital genres, because these instruments get closer to the students' social culture, allowing new practices and activities that will contribute to the development of new knowledge, making them able to communicate properly in this new environment. Referring to this, Blaszkowski (2019) specifies the relationship of genres and social reality:

The work with digital genres [...] can be carried out addressing any theme. They will be the way for the development of students' reading, interpretation, production, communication and expression. The digital media are currently a strong link between students, school, and society, which can provide the meaning of knowledge necessary for learning $[\ldots] .4$

Thus, we understand that digital genres are excellent educational tools for the teaching and learning process, as they enable interaction between the subjects of education through these new literacies, covering all areas of education in an interdisciplinary way.

\footnotetext{
${ }^{3}$ Ibidem, p. 67.

${ }^{4}$ Ibidem, p. 72-73.
} 


\subsection{Digital meme genre}

The meme is a multisemiotic digital genre that has gained prominence in language studies and practices with the advent of social media. According to Lara (2017, p. 11):

The first time [...] that the term meme appears in literature is in the book The selfish gene, by biologist Dawkins (1979). In this book, the author, thinking about cultural replicators, in the field of biology, discusses the need for a name that conveys the idea of a unit of cultural transmission. Thus, analogously to the term gene (which transmits genetic characteristics), and based on the Greek root of mimesis (translated as copy, imitation), Dawkins comes up with the term "meme" to refer, therefore, to that which is copied, shared and disseminated by subjects in spaces of interaction, that is, to that which transmits cultural aspects.

The meme became very well known through Facebook, where countless of them are posted with classic or funny phrases written on pictures of famous people or that somehow combine them with the message, usually making it more comical. Such a composition denotes functions peculiar to this genre such as:

Memes manage to inform and deal with such a serious situation using humor and in the lightest way possible, understands the ability to interpret texts or images, knowing how to relate new knowledge to those that already exist, thus contributing to digital literacy. (Simplício, 2020, p. 08)

According to Simplício (2020), memes that fluently circulate in social media, besides propagating recurrent and pertinent information on a given subject, can easily be accepted as a didactic resource in the educational context.

So, according to this definition: "any cultural knowledge that can be transmitted from one individual to another is a meme. However, the virtual world has appropriated the term to refer to something that is popularized through the internet" (Cavalcanti; Lepre, 2018, p. 02). Thus, the meme, already considered a textual genre of the digital age, has become popular in recent years around the world, manifesting itself in diverse ways in cyberspace.

According to Blackmore (2000, p. 02) who talks about the reproductive aspect that also characterizes it, thus defines the meme

When you imitate someone, something is passed on. This 'something' can then be passed on again, and again, and so it takes on a life of its own. We can call this thing an idea, an instruction, a behavior, a piece of information. But if we are going to study it we need to give it a name.

While Lara (2017, p. 12) treats that:

Thematically, we can say that memes often parody, satirize or criticize authoritative social subjects, historical events, politicians etc., placing new voices before facts and re-accentuating others. Because of this, memes have become a widely used form of expression, and their authorship is - when shared on the net - not possible to detect.

Ferreira, Villarta-Neder, and Coe (2019, p. 130) reiterate the importance of memes for a reflection about ethical engagement in social media. In this sense, memes, "despite their humorous nature, can also fulfill other communicative purposes in different situations of circulation.

As far as the teaching-learning of this genre is concerned, the mentioned authors state that

Memes, due to their interactive nature, enable the mobilization of prior knowledge and the understanding that reading is a social practice, because one does not read only to answer questions, as often happens in school. Reading memes can enable the implementation of practices based on the dialogic nature of language and, consequently, problematize 
issues related to the social and historical dimension, transforming reading into an activity that builds individuals capable of establishing relationships with the world and acting as citizens in it. ${ }^{5}$

That is, memes offer relevant teaching resources that approach the reality of the subject in a meaningful and conscious way, coming from social and cultural practices that, in turn, enable dialogical relations of new languages in various everyday situations.

Thus, the meme, being a very popular and powerful tool in the virtual world, has become a viral phenomenon of information among internet users, because in its composition, it refers to humor in a critical, and sometimes ironic way to internet characters and public people.

\section{Linguistic/Semiotic Analysis}

The axis of linguistic/semiotic analysis in the BNCC brings the need for an analytical and integrated look at the different types of language through semiotics. According to Sena (2018, p. 20) based on the BNCC: "the student needs to do reading and production of different texts, whether oral, written or multisemiotic taking into account the effects of meaning caused by different styles or production situations".

In this way, the BNCC describes this axis:

The Axis of Linguistic/Semiotic Analysis involves the (meta)cognitive procedures and strategies of analysis and conscious evaluation, during the processes of reading and production of texts (oral, written and multisemiotic), of the materialities of the texts, responsible for their effects of meaning, either with regard to the forms of composition of the texts, determined by the genres (oral, written and multisemiotic) and the situation of production, either with regard to the styles adopted in the texts, with a strong impact on the effects of meaning. (Brasil, 2018, p. 80).

Therefore, the use of language/language needs to be analyzed in a contextualized manner to social practices, understanding its forms of use, according to the situation. Thus, the pedagogical work should cover multimodal and multisemiotic texts, using different textual and digital genres with multiple languages, from significant social situations for students. Such genres will be of extreme importance for the contextualization of school knowledge, because their potentials will contribute to a consistent and relevant teaching in a critical and creative way in society.

Sena (2018, p. 20) says that the linguistic/semiotic analysis with multisemiotic texts "should take into account the different forms of composition and style that each of the languages that compose them. In this way, the document aims for linguistic analysis in written verbal, oral, and multisemiotic texts to provide reflection on language.

In view of this approach, educators need to insert these types of texts in their pedagogical practices, because students are increasingly exposed to these types of media genres with different semiotics, present in the media that are conveyed by society.

Ribeiro (2018) says that "semiotic power is the power to deal with signs, produce meaning, handle languages, more than just words, including both reading and writing." However, for the author, this power to interpret verbal and non-verbal languages is insufficient for most people, explaining that

The question of access to knowledge, of the training of readers and text producers, remains current, pertinent and relevant. It is to "be able" to know how to write, since alphabetization, but before, since the contact with written materials; it is to "be able" to handle languages for the production of meaning, whether reading or producing texts; it is to "be able" to perceive how many functions and uses the text and the words have (besides other languages, such as image or sound, for example). It is to "empower", therefore, to offer the means for people to read, to read well, to

${ }^{5}$ Ibidem, p. 131. 
react and to produce texts. And the ways of doing this have changed over time, including technological changes. (Ribeiro, 2018, p. 114-115).

In his research, Ribeiro ${ }^{6}$ reflects on what it means to write nowadays, stating that there are numerous languages to produce a written text nowadays. Therefore, it is necessary "to be aware that writing is historically and socially situated, that is, not a or writing. It is alive and depends on many conditions, including and mainly technological ones". Therefore, writing is a process that occurs in the history of reading and ways of writing, in which language is produced with meanings.

$\mathrm{n}$ this regard, the author clarifies:

The techniques and technologies of writing available to us today are one more phase of this history, which does not despise any previous one. Moreover, I consider that there is integration, that there is increment, and not competition between ways of reading and writing. We have, therefore, a complex scenario in which processes of various forms coexist, as well as various genres and texts. Fundamentally, we do not learn blindly, ways of producing meanings that come from a superior, unreachable instance. Rather, writing and reading are blended into our ways of life, our experiences, our way of operating in society. (Ribeiro, 2018, p.85-86).

In this way, we understand that semiotic power is the signification of all language modalities, represented in its various forms and linguistic or non-linguistic manifestations, contemplating the social, cultural, and historical aspects.

Ribeiro $^{7}$ also talks about the orchestration of languages, of multimodality: "Students - and any of us, ultimately - can produce texts that depend on the management of words, images (drawings, photos, etc., which are different modalizations of the 'image')". In this sense, digital technologies expand the semiotic power of multiple languages, but it is necessary to have a domain over these tools, expanding the forms of expression in a critical and reflexive way.

\section{Generative Path of Meaning}

For Fiorin (2017, p. 151): "[...] semiotics is a theory of all systems of signification of discourses manifested by any types of text (a verbal text, a painting, a film, an opera, an advertisement, a sculpture, and so on)".

The author's semiotic theory is based on the discourse process as a generative path, which starts from the simple and abstract and moves to the more complex and concrete, thus feeding the semantics of the text. This process suggests a view of the text as made up of homogeneous components that increase according to the generative path, each component being subject to description.

According to Fiorin (2007), the generative path of meaning is a model of analysis and predictability, consisting of three levels: the fundamental level that analyzes the semantics and syntax of the text; the narrative level that examines the states and transformations of the compositions; and the discursive level that studies the problems of argumentation and the ways in which one interlocutor addresses the other.

At the narrative level, the author ${ }^{8}$ works with narrativity which is the transformation situated between two successive and different states, that is, when one has an initial state, a transformation, and a final state. Warning that "for these transformations to occur, there needs to be in the text the narrative roles, played by subjects and objects, which can be represented at a more superficial level by things, people or animals".

At the discursive level, "the projections of the enunciation in the enunciatee are studied, the procedures of installation of time, person, and space in the discourse; the relations between the enunciator and enunciatee, [...]" (Fiorin, 2017, p. 154).

\footnotetext{
${ }^{6}$ Ibidem, p. 115.

${ }^{7}$ Ibidem, p. 122.

${ }^{8}$ Ibidem, p. 153.
} 
Such analysis served to identify how the learners face and view the reality that surrounds them and their possible solutions to society's problems.

That said, the generative path of meaning stems from the articulation of the elements that make up a text, that is, it refers to the content plane conveyed by a plane of expression and its significations, represented by different natures, verbal or non-verbal.

We will demonstrate an analysis of the generative path of meaning, used as a stimulus for the participants of this research, the meme of title "Finally emerged the fourth monkey" (Salum, 2019) as shown in Figure 1 below

Figure 1 - Finally the fourth little monkey has appeared.

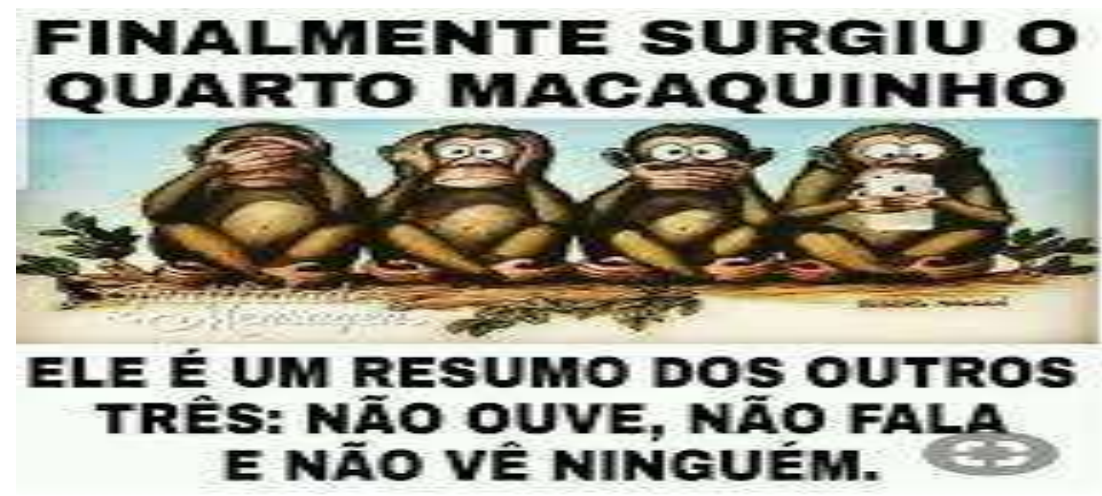

Source: Josimar Salum's Facebook Page9.

According to Salek ${ }^{10}$ (2020): "usually the monkey symbols are used in jest to say that someone did not want to see, hear, or speak something. The third one, the one covering the mouth, is also sometimes used as a promise to keep a secret". Although it has various interpretations, in Japan, according to the Better with Health website (2018): "the classic story of the 'three wise monkeys' of the Toshogu shrine conveys a simple teaching and proposes a reflection that never goes out of fashion: we must be careful about what we say with what we hear, and also with what we see."

With the ultra-modern adaptation shown in figure 01 above, the fourth little monkey that sees, hears, and speaks nothing, really! That is, he doesn't interact with anyone around him for the reason that he is addicted to his cell phone, is an ultra-modern adaptation of "the 3 wise monkeys", a Japanese sculpture from the 7 th century. Given the current context, figure 01 refers to a "real evolution of the species" (Medeiros, 2020).

To analyze Figure 1, we focus on Fiorin's (2017) concept of the generative path of meaning that shows how meaning is produced and interpreted. Thus, we took into consideration the exposed information about the origin of the classic story of the "three wise monkeys" and the ultra-modern adaptation of the ourth little monkey who does not interact with anyone around him for the reason that he is addicted to his cell phone, being relevant information for the analysis.

That said, we analyze, based on Fiorin (2017), Figure 1 going through the three levels: at the fundamental level, we identify the relationship between socialization as euphoric $\mathrm{x}$ antisocial (technology) in the condition of dysphoric as a semantic category of the text. There is the affirmation of technology and the denial of technology, in the sense that everyone is connected at the same time, but because of the cell phone they no longer interact with each other. There is also the affirmation

\footnotetext{
${ }^{9}$ https://www.facebook.com/josimar.salum/posts/finalmente-surgiu-o-quarto- monkey/1044441419076264/>. Accessed on: 15 feb. 2021.

${ }^{10}$ She graduated in journalism from the Federal University of Rio de Janeiro (UFRJ) in 1997. Before joining BBC Brasil in 2001, she worked as an Economy reporter at the Rio de Janeiro newspaper O DIA. At the BBC, she was a producer and presenter and passed through World Service programs such as "The World" and "World Update". She has an MA in Development Studies and Social Anthropology from Birkbeck College, University of London. She has been editorial director since December 2013.

Source: Available at: <https://www.bbc.com/portuguese/institutional-36202452〉. Accessed on: 06 Mar. 2021.
} 
of socialization and the denial of socialization, because at the same time it brings you closer to someone, in terms of distance, it moves you away in the sense that there is no more face-to-face communication between people.

At the narrative level, narrativity occurs in the following way: if before people were closer to each other, with more interaction between them, when there weren't absurd amounts of electronic devices around them, today, with the advance of technology and the easier access to the internet, this scenario has changed. People, at the same time that they are close to each other through technology, keep distant from each other, because they no longer talk face-to-face, but through the means of digital communication, that is, they no longer interact with each other. Thus, the initial state of the human being without the cell phone (x) technology materialize as distant from each other because of the lack of interaction caused by the insertion of technological devices.

On the discursive level, the relationships between the subjects on the narrative level are concretized by the closeness and the distance between people caused by the increasing advance of technology. In this way, the estrangement appears thematized by social isolation, which is figurativized by the fourth little monkey that does not see, does not hear, and does not speak anything, because he does not interact with anyone around him for the reason that he is addicted to his cell phone.

\section{Method}

This study resulted in a field research, participant observation (Angrosino, 2009) that we conducted during the period from August to November of the year 2019. Therefore, this work occurred in three moments.

In the first moment, we made the presentation of the selected meme to the class. Next, the authorial production of the memes occurred, and then we carried out the socialization of the memes produced. Before the steps, we read the class profile and identified a great interest of the children in using cell phones. During the observation, we noticed the interest and ease they had in handling the teacher's cell phone. We noticed how the students communicated frequently, through conversations, therefore we noticed a strong bond with technology. Thus, we developed the research with the digital meme genre, with the objective of discussing digital literacy in elementary school 1. For the execution of the tasks, we used: paper, pencil, colored pencil, and eraser.

Figure 2 - Production of memes by 3rd grade students.

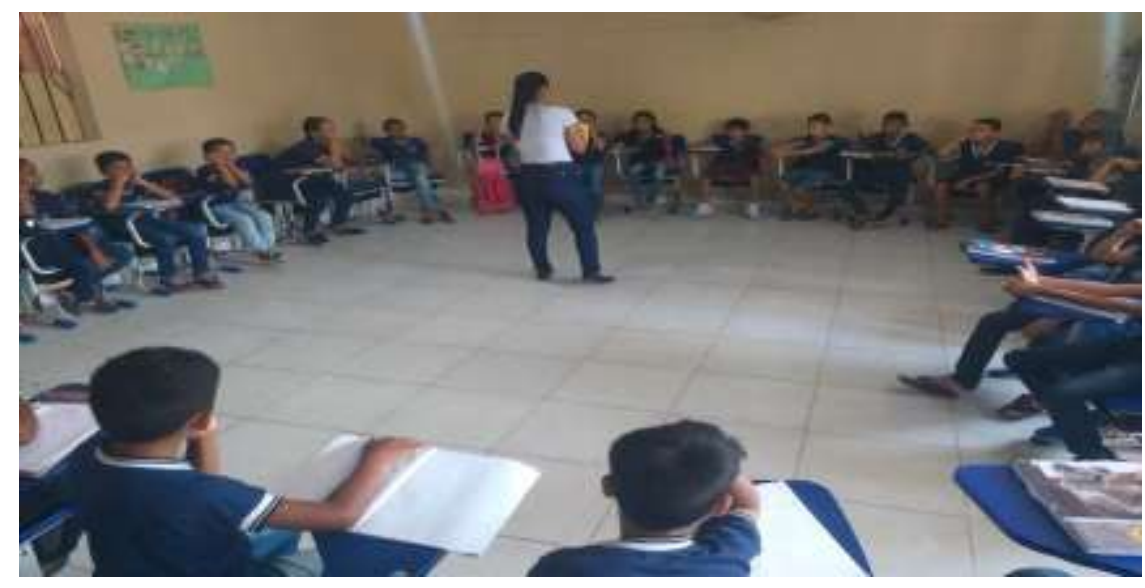

Source: Authors (2019)

\section{Construction of the Information}

The research occurred during our teaching internship I, in the State Elementary School "Bom Jardim" that serves students from 1 st to 5 th grade of elementary school 1 , in two shifts: morning and afternoon, located in a peripheral region in 
the city of Ananindeua, in the neighborhood Águas Lindas, at Rua Osvaldo Cruz, S/N. In the period from August to November of the year 2019.

According to the data of the Census/2020, the State Elementary School "Bom Jardim" has in its infrastructure: school meals for students, filtered water, artesian well water, public network energy, cesspool, garbage destined for periodic collection, internet access, broadband. Teaching facilities such as: 6 classrooms, a principal's office, a teacher's room, a resource room, a multipurpose room for Specialized Educational Services (AEE), a kitchen, a bathroom suitable for students with disabilities or reduced mobility, a secretary's office, a bathroom with shower, a pantry, an open patio. Equipment such as: TV, DVD, stereo.

\subsection{Research Participants}

Thirty-eight students took part in this study, divided into 7 (seven) groups, being 4 (four) groups of 5 (five) students and 3 (three) groups of 6 (six) students, with ages between 8 and 11 years old, from the 3rd year of elementary school I, in a state public school, located in the city of Ananindeua-PA.

\subsection{Research material}

The research material was composed from the meme "Finally the fourth little monkey appeared" (Salum, 2019) as per Figure 3 below:

Figure 3 - The fourth monkey finally arrived.

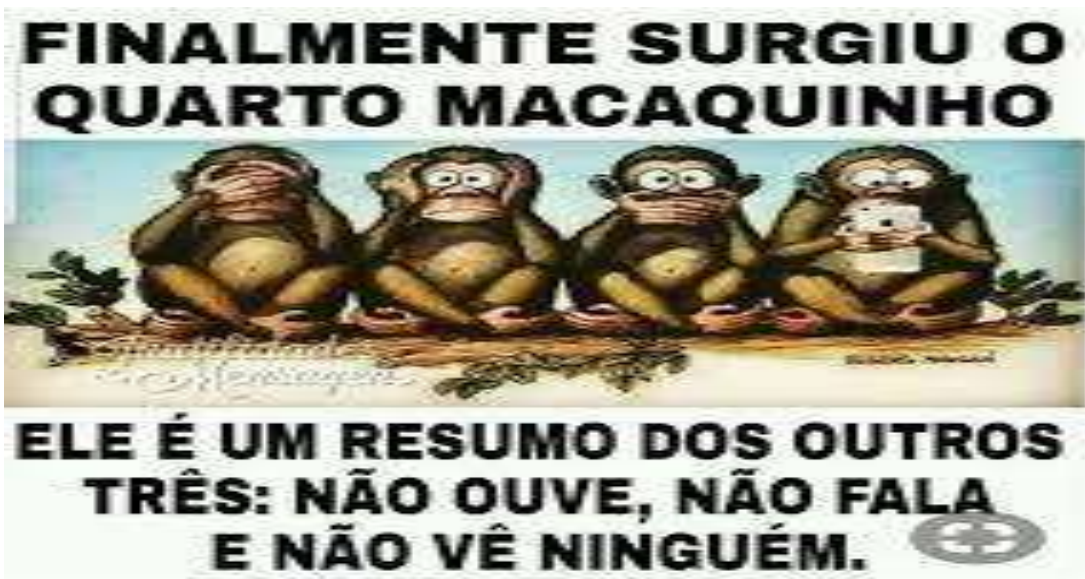

Source: Josimar Salum's Facebook Page.

Why did we choose the meme "Finally the fourth little monkey appeared" in the picture above? The choice of meme was based on the observation we made during the internship, in which we found that many students were already immersed in the digital context from an early age and had some kind of contact with cell phones, tablets, notebooks, computers, etc., and that they also had some contact with the images that show the three monkeys in different poses, covering their ears, eyes, and mouths in the common emojis of WhatsApp, Facebook, and Instagram conversations. Therefore we conducted a search on the web pages and selected the meme "Finally the fourth little monkey has emerged".

\subsection{Participants' task}

In the first moment, we made the presentation of the selected meme "Finally appeared the fourth little monkey" to start the research, after presenting to the students the objective of the class, some questions were asked in a conversation circle, 
for example about what is a meme, its characteristics, functionality, medium of conveyance and production? Have any of them ever heard of or made any kind of meme? Do they have any contact with a cell phone, notebook, or computer? Do they chat through whatsapp, facebook or Instagram messages? And they were answered orally: most of them answered that meme is "a joke", or "a funny thing", "that are found on the internet, like Facebook, Instagram and Whatsapp", "that are made by applications"; some of them reported that they have already produced memes using these applications, stating that the application "is very easy to use". Many of them stated that they use their parents', grandparents', uncles', and cousins' cell phones, and that they chat through social networks. Afterwards, we recorded in notes, and within the answers, it was possible to make a previous survey about what each student brings in their cultural baggage in relation to the digital meme genre.

In the second moment, we divided the class into 4 (four) groups of 5 (five) members and 3 (three) groups of 6 (six) members, totaling 7 (seven) groups. This division is justified because we believe that group interaction significantly favors learning, since for Vygotsky (1989) "activities carried out in groups together offer enormous advantages that are not available in individual learning environments. Next, we asked them to create memes about any subject, using their creativity through hand illustrated drawings, with the following command: "create a meme, produced through drawings, about any subject that has marked your trajectory, with some current event that they have witnessed, lived, or read".

In the third moment, we socialized, before the class, the memes produced by each group, in which they themselves explained the themes chosen for the production of the memes. At this point, each group presented orally the information that was between the lines of the digital meme genre they produced, taking into account their knowledge of their reality.

\section{Data Analysis}

We analyzed the 7 (seven) memes produced by the 7 (seven) groups of students from the 3rd year of elementary school 1, based on Fiorin's theory (2017), specifically, the generative path of meaning, in its three levels. In these terms, the analysis of the figures followed the order: a) contextualization of the meme produced by the 3rd grade students; b) description of the meme produced by the 3rd grade students; c) generative path of meaning of the meme produced by the 3rd grade students.

We begin the analysis by the following Figure 4, the group started from the media release that occurred in August 2019, when Brazil was the scene of major fires in the Amazon.

Figure 4 - The Amazon is on fire and there is a giraffe.

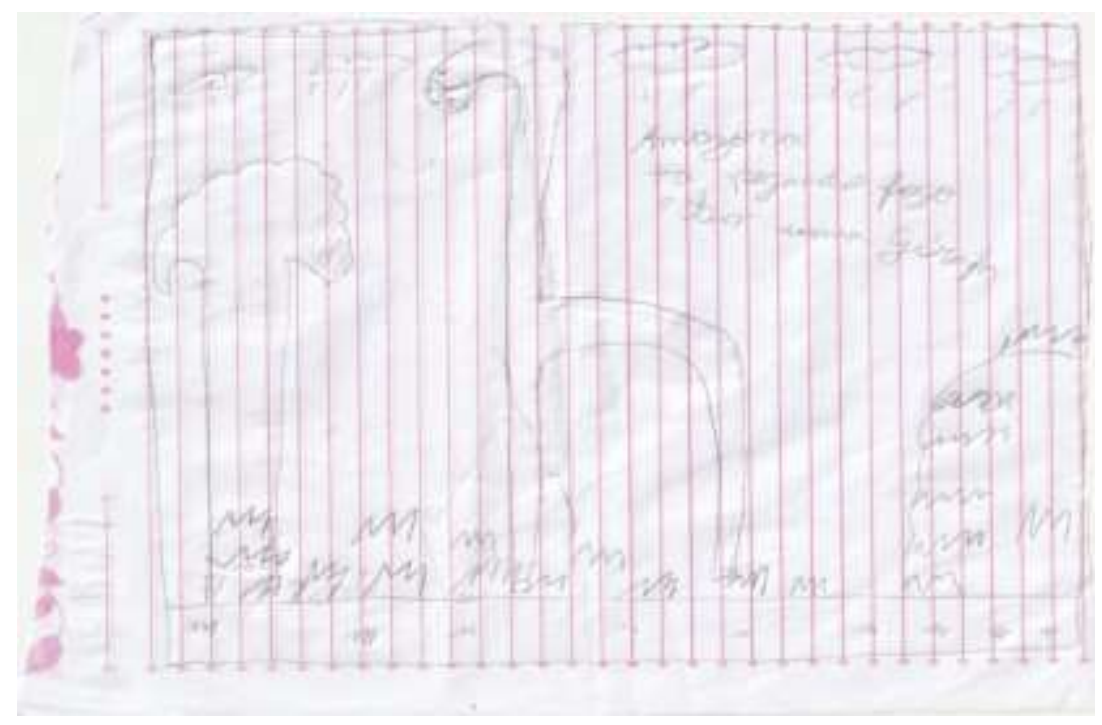

Source: Authors (2019). 


\section{a) contextualization of the meme produced by 3rd grade students}

In the midst of the tragedy that impacted the Amazon fauna and flora, mobilizations on several fronts for the defense of biodiversity were glimpsed, one that drew attention was the blogger and influencer Hosana de Lima who went viral on the Internet after making a body painting with animals that are not part of the Amazon fauna.

Among the animals painted on the body of the blogger and influencer, was a giraffe, the situation was the trigger for the dissemination of memes in virtual networks; although the intent of the post was to generate awareness and alert the public about the fires that were occurring in the Amazon, the effect was contrary and the author was the target of criticism.

\section{b) description of the meme produced by 3rd grade students}

To create the meme the group of figure 04 above, the students used only pencil and paper to draw a giraffe in the middle of the Amazon forest, with the phrase "The Amazon is on fire and there's a giraffe" which came from the catastrophe caused by fires in the Amazon, widely reported in the news and social media.

\section{c) generative path of meaning of the meme produced by 3rd grade students}

At the fundamental level, we identify the relationship between nature as euphoric $\mathrm{x}$ wealth as dysphoric as a semantic category in the text. There is the affirmation of nature and the denial of nature, in the sense that everyone is aware of the harm they are causing to humanity and nature, but because of ambition, power and greed, they continue to burn. Just as there is also the affirmation of wealth when they set fire to the Amazon, and the denial of wealth when they go out on the streets making others aware so that they stop burning against the Amazon.

On the narrative level, narrativity occurs as follows: we have the issue of the preservation of the Amazon, in which everyone needs to become aware and, from this, mobilize to protect the forest. There is also the issue of man's ambition in search of power, mobilized by capitalist interest, and therefore not caring about anyone but his own pocket. Thus, the initial state of the human being concerned and conscious about his neighbor and nature (subject) $\mathrm{x}$ capitalism (anti-subject) is materialized with the fires caused by ambition.

On a discursive level, the relations between the subjects on the narrative level are concretized as being concerned with nature and with man's ambition that has been causing the increasing increase of fires. In this way, this concern appears themed by social awareness, which is figurativized by the giraffe, in which the group justified the production carried out under the reflection that in the Amazon there are no giraffes.

To create the meme of Figure 5 below, the group used the context of fake news, one of the most talked about issues in the media, especially by social media.

Figure 5 - Fake news about pregnancy.

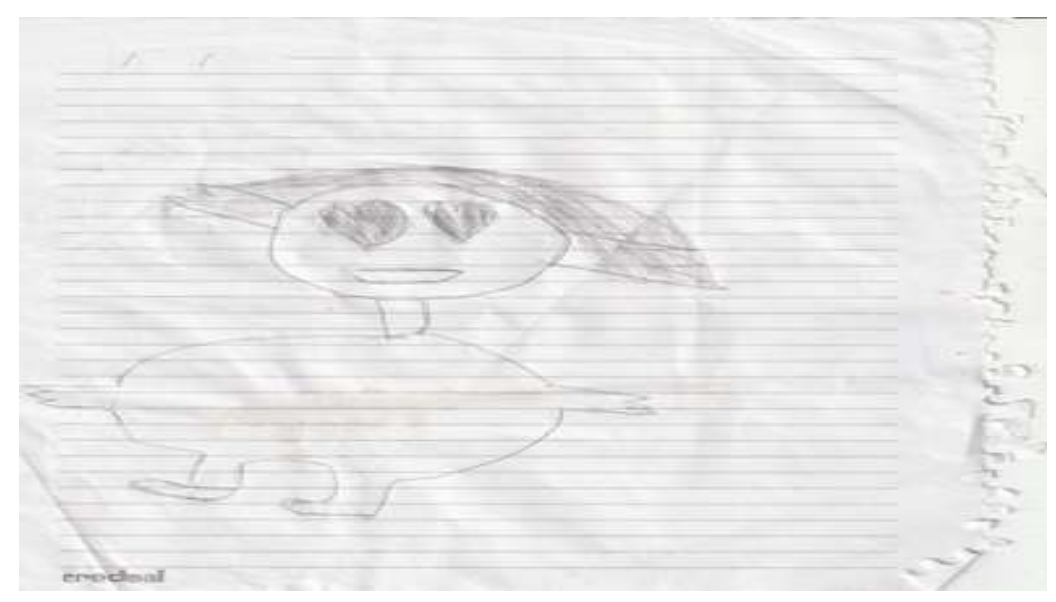

Source: Authors (2019). 


\section{d) contextualization of the meme produced by 3rd grade students}

We are living in a time when most citizens have daily access to a lot of true and false information. This is a reality that comes close to the social life of children, being one of the controversial and much commented subjects on the internet and television news. For this reason, the group of figure 05 chose this subject, since it was a topic that they had some knowledge, and that was even discussed and debated in the conversation circle, before the elaboration of the memes. Therefore, the group started from the context of fake news.

- description of the meme produced by the 3rd grade students

To create the meme, the group in Figure 5 used only pencil and paper to draw the picture. They used only the image, without any written text. However, at the moment of socialization, they explained orally in a critical and reflective way how they produced the meme. The team presented the meme about the researcher of this work, in which she is drawn in a rounded shape. One of the members of the group justified it by saying that the researcher was pregnant, for this reason they drew her "fat". Then, another member of the same team said that it was fake news, because the researcher was "thin", therefore it was fake news.

\section{a) Generative path of meaning of the meme produced by the 3rd grade students}

At the fundamental level, we identify the relationship between truth as euphoric vs. lies in the condition of dysphoric as a semantic category of the text. There is the affirmation of the truth and the denial of the truth, because in the first moment when the news is given, everyone believes it, but soon after the lie is discovered. Just as there is, also, the affirmation of the lie when the fake news is shared, and the denial of the lie when they no longer know who else to believe.

At the narrative level, the narrativity occurs in the following way: we have the issue of the news about the researcher's pregnancy and the issue of the false news. In this way, the initial state is the fat researcher $\mathrm{x}$ thin researcher, which is materialized in a lie caused by the news that is not true.

At the discursive level, this lie appears themed by the fake news, which is figurativized by the fat researcher, in which the group justified the production saying that it was a fake news, because the researcher was not fat, but thin.

In Figure 6, entitled "Neymar crying in the world cup", we interpreted the following data.

Figure 6 - Neymar crying in the world cup.

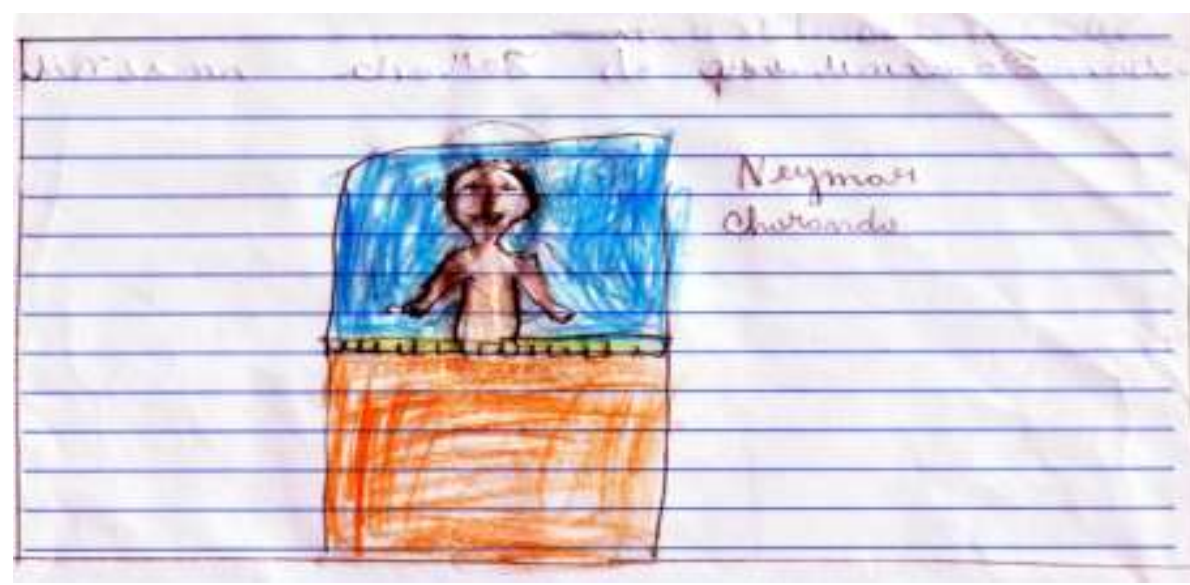

Source: Authors (2019), 


\section{a) contextualization of the meme produced by 3rd grade students}

The group in Figure 6 chose to produce a meme of the player Neymar who had been suffering constant attacks from the media for his poor performance in the 2018 World Cup, being the target of much criticism. Neymar was heavily criticized for falling too much in games, many people interpreted it as "cai cai cai", saying that he exaggerated in the supposed simulations. The striker was a worldwide subject, mocked by the international media for his bad performance on the field. The player's bad behavior was also much criticized. Neymar ended up becoming a laughingstock on social networks around the world for his excessive foul simulations.

\section{b) description of the meme produced by 3rd grade students}

The group used pencil, paper, and colored pencils in blue, orange and brown to create the meme shown on picture 06. Neymar was drawn in the middle of a rectangle, with the phrase "Neymar crying", justifying that this was the player crying on the soccer field during the World Cup, explaining that Neymar was crying because of the booing and consequences of his performance on the field.

\section{c) generative path of meaning of the meme produced by 3rd grade students}

At the fundamental level, we identify the relationship between the player's performance on the field as euphoric $\mathrm{x}$ concern in the condition of dysphoric as a semantic category of the text. There is the affirmation of the player's performance and the denial of the player's performance, because at the same time that we know he is a good player, he also shows himself as a bad player. Just as there is, also, the affirmation of concern when he cries on the field, and the denial of concern when he, even worried, continues with his bad behavior in the game.

At the narrative level, we have the issue of Neymar worrying and the issue of the media. Thus, the initial state is of the worried player $x$ media that materialize in a crying caused by his bad performance in the game matches.

On a discursive level, this crying appears themed by criticism, which is represented by the player Neymar crying on the field, in which the group justified the production by explaining that Neymar was crying because of the booing and consequences of his performance on the field.

The following Figure 7, still in the context of the 2018 World Cup, the group in Figure 07 created a meme depicting the crying of the player Neymar at the end of one of the matches, which ended with the victory of the Brazilian team.

Figure 7 - Neymar crying with relief.

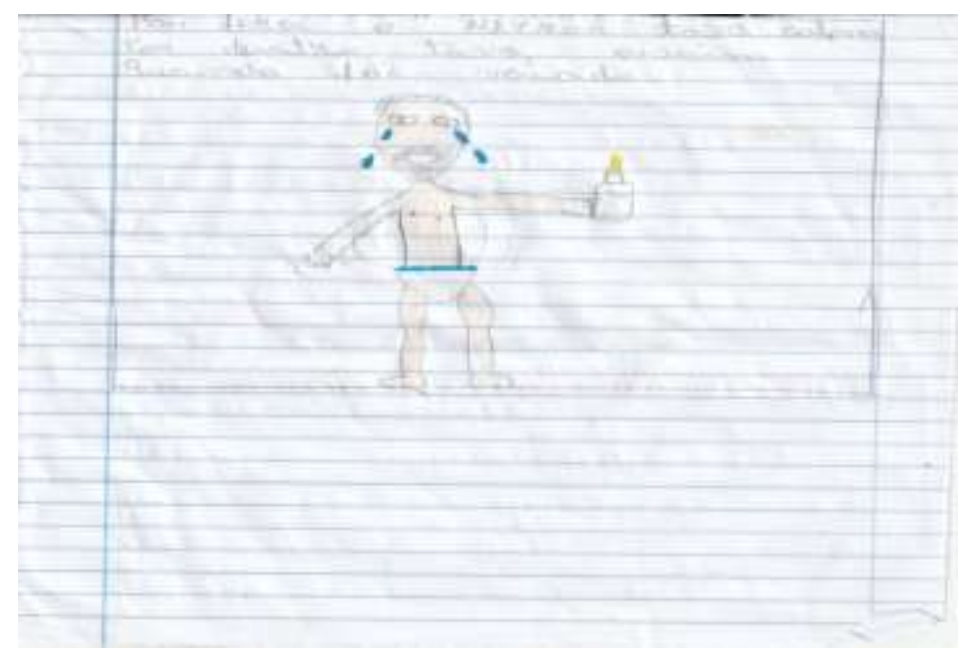

Source: Authors (2019). 


\section{a) contextualization of the meme produced by 3rd grade students}

Neymar's crying was also the target of much criticism by the international press. For many, it was nothing more than pretending, because people no longer believed in the player because of the staging of games, where the player easily simulated false fouls in an attempt to manipulate the referee in his favor. For others, this crying represented a relief for the player, because as the pressure was all on him for the much desired victory to come, and when the national team managed to finish the match with victory, Neymar could not stand it and cried.

\section{b) description of the meme produced by the 3rd grade students}

To create the Figure 7 meme, the group used pencil, paper and colored pencils in blue and yellow, drawing the player with white underwear, holding a bottle, with the following phrase: "Neymar outwardly calm, inside he was like that when he was booed", the group justified the production saying he cried, because he couldn't take the pressure on him anymore.

\section{c) generative path of meaning of the meme produced by the 3rd year of elementary school students}

At the fundamental level, we identify the relationship between concern as euphoric $\mathrm{x}$ criticism in the condition of dysphoric as a semantic category of the text. There is the affirmation of concern and the denial of concern, because he was being heavily criticized by the media. Just as there is, also, the affirmation of criticism when he knows he is not playing well, and the denial of criticism when he tries not to care about what they are saying about him.

At the narrative level, we have the issue of worry and the issue of the media. Thus, the initial state is the worried $\mathrm{x}$ booed that materialize in a cry caused by his poor performance in the game matches.

On a discursive level, this crying appears themed by relief, which is figurativized by the player Neymar crying on the field, in which the group justified the production by explaining what they felt when the national team came out with the victory.

The group in Figure 8 brought, for the production of the meme, the context of the burning in the Amazon.

Figure 8 - The struggle of good and evil to save the planet.

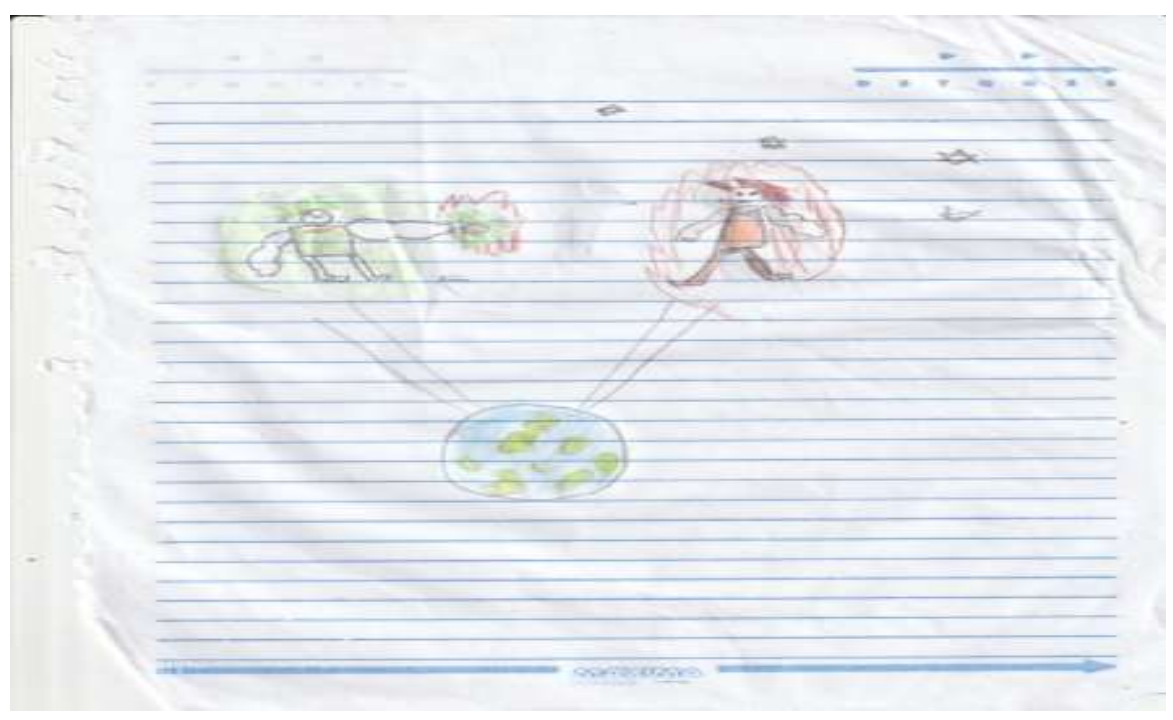

Source: Authors (2019).

\section{a) contextualization of the meme produced by 3 rd grade students}

In the year 2019, the country faced an episode of great tension with the increase of fires that occurred in the Amazon region. This was an international issue, because due to the smoke generated by the various outbreaks of fires, many cities in the 
country were left with dark skies, generating fear and dread among people not only from those cities, but from all over the country. Several NGOs, firefighters, and environmentalists mobilized to contain the fire that was spreading throughout the Amazon region.

\section{b) description of the meme produced by 3rd grade students}

In the creation of this meme, the students justified it by saying that it was a fight between good and evil to save the planet. To create the meme, the students used pencil, paper and colored pencils in green, red and blue. The group drew two people, one in green, symbolizing good, and the other in red, symbolizing evil; both directed towards a circle that symbolized the planet earth.

\section{c) generative path of meaning of the meme produced by 3rd grade students}

At the fundamental level, we identify the relationship between environmentalists as euphoric $\mathrm{x}$ fire in the condition of dysphoric as a semantic category of the text. There is the affirmation of fire and the denial of fire, as we have the burning against the planet. Just as there is, also, the affirmation of environmentalists when we talk about protection, and the denial of environmentalists when their struggles seem to be far from the end.

On the narrative level, we have the question of good and the question of evil. In this way, the initial state fights vs. fires that materializes into a struggle.

At the discursive level, this fight appears thematized by the fight against deforestation and Amazonian fires, which is figurativized by good and evil, in which the group justified that the production was about a fight between good and evil to save the planet.

The group in Figure 9 produced a meme, from the context of the deforestation of the Amazon Rainforest.

Figure 9 - Deforestation of the Amazon.

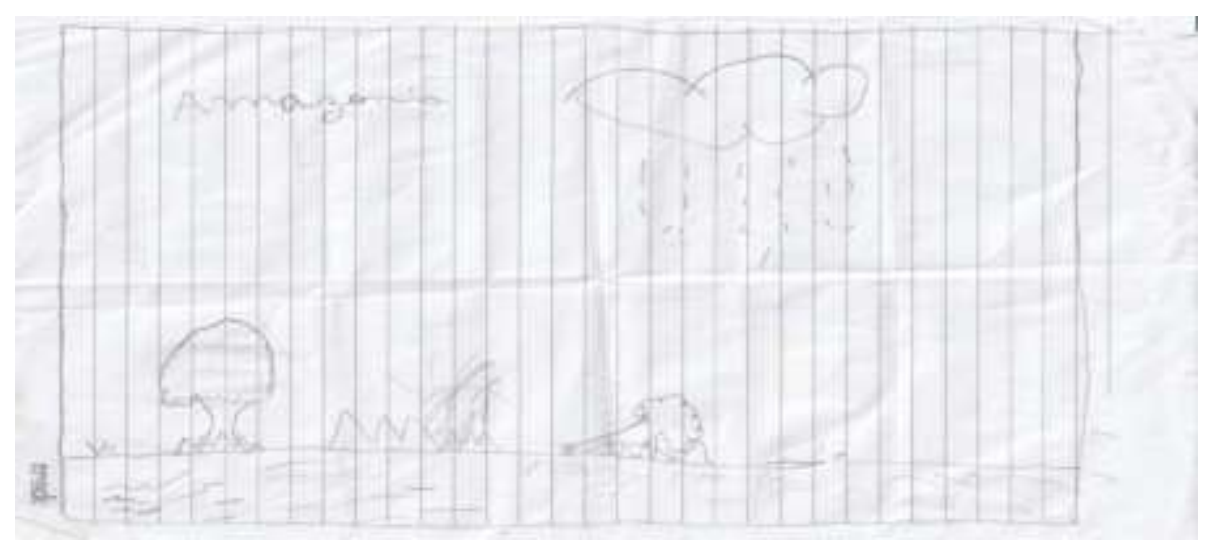

Source: Authors (2019)

\section{a) contextualization of the meme produced by the 3rd grade students}

In this period, the news was reverberating every day, because there was a huge concern about the Amazon that was suffering more and more the impact of deforestation and fire outbreaks, day after day, alerting the whole world.

\section{b) description of the meme produced by the 3rd grade students}

To create the meme, the group used only pencil and paper to draw the picture. They used the word Amazon on the image. They drew two trees, one standing and the other on the ground, fallen. They also drew the forest being burned and a cloud with water droplets, symbolizing rain. 


\section{c) generative path of meaning of the meme produced by the 3rd grade students}

At the fundamental level, we identify the relationship between rain as euphoric $\mathrm{x}$ burned in the condition of dysphoric as a semantic category of the text. There is the affirmation of the rain and the denial of the rain, because in the Amazon it rains a lot, but it was not enough to prevent the fires. Just as there is, also, the affirmation of the burning when we talk about Amazon devastation, and the denial of the burning when there are rains, in which the outbreaks of fire decrease.

On the narrative level, we have the initial state of the tree standing $\mathrm{x}$ tree on the ground, which materialize in the deforestation, caused by the fires. At the discursive level, this forest appears thematized by the deforestation of the Amazon, which is figurativized by the tree on the ground. For the production of the meme in Figure 10 below, the group also used the theme of fake news, a subject that had a lot of repercussions at the time.

Figure 10 - The wedding.

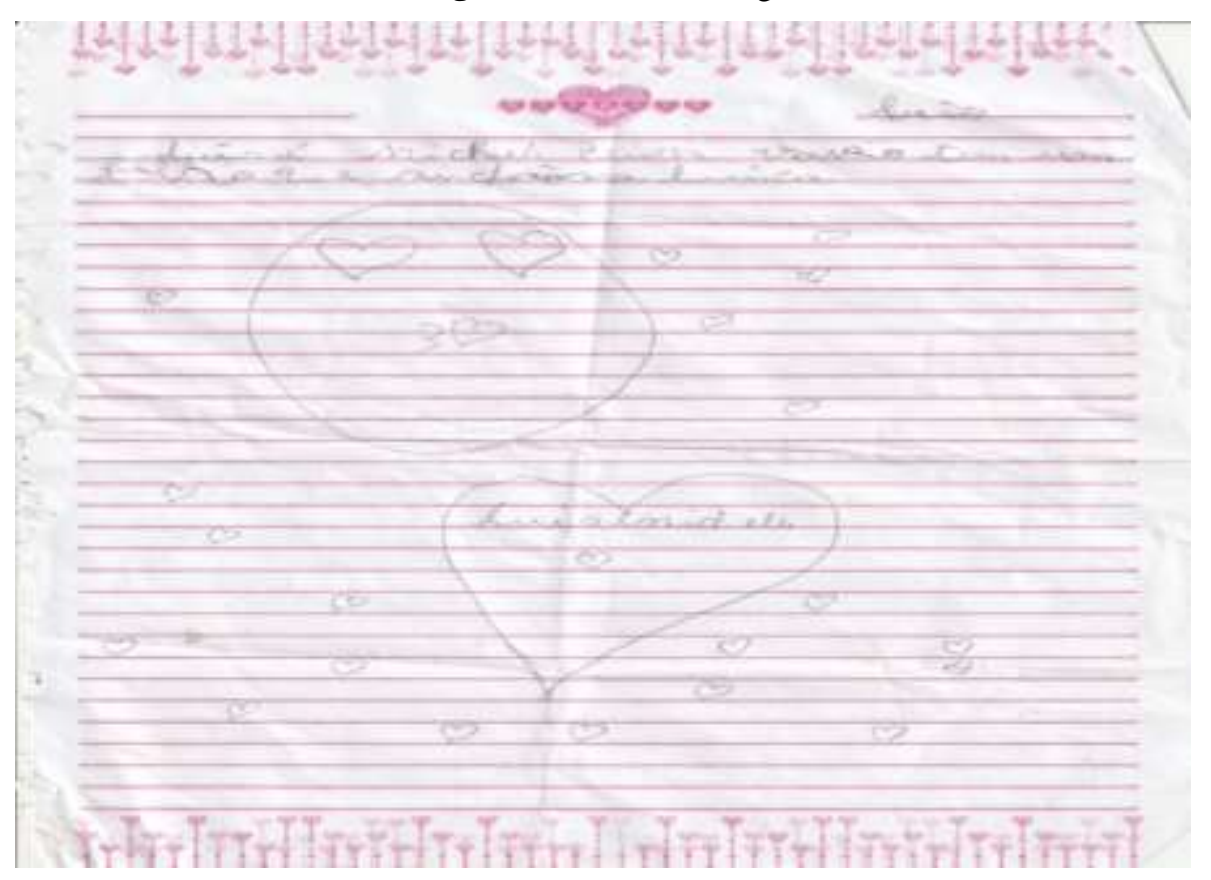

Source: Authors (2019).

\section{a) contextualization of the meme produced by 3rd grade students}

In Brazil, the manipulation of images has intensified during election times, with fake news quickly shared on social networks, causing greater frustration and danger to society.

\section{b) description of the meme produced by the 3rd grade students}

To create the meme, the group used only pencil and paper to make the drawing. They used the image with the following sentence: "Luís and Michele got married and had a daughter named Luiza". They made a drawing of a circle, symbolizing the emoji with the eyes of hearts in love, and a drawing of a heart written "Luis and Michele", symbolizing the union of the two. The group socialized the production explaining that it was a fake news, because "Luis and Michele" were only friends and that this was fake news trying to end their friendship.

\section{c) Generative path of meaning of the meme produced by the 3rd grade students.}

At the fundamental level, we identify the relationship between nature as euphoric $\mathrm{x}$ culture as dysphoric as the semantic category of the text. There is the affirmation of nature and the negation of nature, as it refers to the two in love. Just 
as there is, also, the affirmation of culture when we talk about marriage, child and family, and the denial of culture, because everything was just a lie.

On the narrative level, we have the question of the lie and the question of the truth. Thus, the initial state marriage (x) friendship, which materialize into a lie.

At the discursive level, this marriage appears thematized as fake news, which is figurativized by the passionate emoji and the heart written: "Luis and Michele", in which the group justified the production explaining that everything was just a lie, because "Luis and Michele" were just friends.

\section{Results and Discussion}

The 7 (seven) groups presented, in their productions, satisfactory elements consistent with the chosen themes. The drawings were essential so that we could perform our analyses focused on the production and interpretation of meanings, based on the three levels of the generative path of meaning of Fiorin (2017), intending especially the linguistic/semiotic analysis proposed in the BNCC (Brazil, 2018). In this sense, we consider the different forms of composition and style that each of the languages that compose them, whether in written verbal, oral and multisemiotic texts, providing a reflection on the use of language. In addition to creativity, the children themed their memes with recurrent and relevant information in our society.

Such results show how involved and informed they are about the facts that happen around them. At the moment of socialization, the third grade students demonstrated firmness and knowledge about the chosen theme to create their meme, explaining every detail in a critical and reflective way.

We highlight that, during the elaboration of the memes, it was possible to observe the students' involvement in each step of the production. All of them showed great interest in knowing how we can create memes just by drawing on paper, and most importantly, they understood the function of the meme as a digital and multisemiotic genre. Many of them reported that they had already created memes with pictures of their own classmates or family, just for fun. Perhaps this facilitated the good performance of the proposal. Knowing what a meme is about is fundamental, as well as understanding the messages they convey with the objective. In addition, the memes produced revealed social aspects related to the students' lives, such as fake news, deforestation of the Amazon, soccer, the World Cup, and the social relationships present in it.

With the analysis of the seven memes produced, we consider that it is essential to introduce digital literacy to 3rd grade students, because according to the BNCC, it is necessary to teach the specificities of each language practice associated with the digital multi-semiotic genres that circulate in digital media, stimulating the critical and reflective sense of these students from an early age. Thus, the teacher must make a pedagogical plan that stimulates the students' critical view of these new genres with new languages.

Proposals like the one we have developed favor us to keep in mind that working with multisemiotic and digital genres is not an impossible task, but rather a way to provide students with knowledge and improvement of the multiple languages that make up the interaction processes of our daily lives, because as Sena $(2018$, p. 28) justifies no doubt this approach is an advance in the teaching-learning process, because today students are, all the time, exposed to media genres with different semiotics and the educational system cannot leave aside these multisemiotic texts that are every day more present in the daily life of society.

Finally, the analysis of the seven memes produced by the third grade students revealed to us the possibilities and potential for working with the multisemiotic genre, the meme. In all productions we observed the articulated language practices, such as speaking, reading, writing, and semiotic linguistic analysis, aligned with the BNCC. Thus, by producing the memes, it was possible to work on orality, accomplished through socialization, as well as writing through sentences or just words developed by the students. We also noticed the curiosity of the groups when they read their classmates' productions, and 
then the attempt to rewrite their productions with the intention of correcting some wrong word, by paying attention to the other classmates' speeches, as well as the reflection they did to produce the memes. Soares (1998) confirms that the ideal would be to teach literacy through literacy - to teach reading and writing in the context of the social practices of reading and writing, so that the individual would become literate and literate at the same time.

In this context, it is up to the school to bring to classrooms the reflection about the effective performance of students in language practices that involve reading and writing, always seeking to problematize and analyze the experience of performing these practices.

\section{Final Considerations}

With the result of the analysis of the memes' productions, we returned to our goals, which was to discuss digital literacy in Elementary 1, considering the proposal of the Common National Curricular Base, especially the linguistic/semiotic analysis. By resuming our hypothesis that 3rd grade students in Elementary 1 are being enabled to develop critical and reflective discernment regarding the reading and writing practices of multisemiotic texts, the meme. We found that it was confirmed, as students demonstrated that they were able to develop meaningful skills in language practices and to position themselves critically and reflectively in the reading and writing practices of multisemiotic texts.

The research analyzed 7 (seven) memes produced by 38 students, divided into 4 (four) groups of 5 (five) students and 3 (three) groups of 6 (six) students, totaling 7 (seven) groups of 3rd grade students from a public school in Ananindeua/PA. After that, the participants' task consisted of three stages: 1) reading the meme "Finally the Fourth Little Monkey Appeared"; 2) production of memes about subjects of interest to the students; 3) socialization of the memes by the students. The results pointed out that the participants presented skills of language practices, demonstrating critical and reflective sense of multisemiotic texts, the meme.

We were able to infer that it is possible to work with 3rd grade students in the classroom with teaching practices as proposed in the research. We found that teaching digital genres such as the meme to 3rd grade students is not such a simple task, since it requires skills to interpret and produce the texts of the digital sphere. Therefore, it is essential that teachers are prepared and trained to work with the most varied digital and multisemiotic genres that circulate in social media.

Regarding the productions developed in the research on the digital genre meme, the children had to use their skills to draw memes when performing the activity proposed in the research. We know that teaching practices are still very much linked to the culture of printed texts and textbooks, but this does not prevent the school from working, from an early age, the digital literacy with children, because associating digital genres, such as the multisemiotic ones, to language practices, especially semiotic linguistic analysis, adapting them to the students' reality, will develop skills and abilities important for their cognitive formation.

Thus, it was possible to state that the digital genre meme contributes to the process of digital literacy in the 3rd year of elementary school, since it proved to be effective in contributing to the integration of language practices, articulating them among themselves, as a potentiality for reflective action in the teaching and learning process of children and in the constitution of critical citizen training.

Therefore, it is fundamental that schools are attentive to insert practices that teach their students to use digital resources correctly and safely. After all, the children who are being born now, called digital natives, are fully inserted in the context of intense use of technologies, but they need to focus on the development of fundamental skills for the future, helping them understand how the digital world works, the information that circulates there, and all the tools and resources available. 
In this case, when the teacher inserts in the classroom the digital meme genre, as a pedagogical resource to combat misinformation, he makes students able to analyze an information and realize whether it is true or not, being this one of the main ways to combat the spread of false news shared through social networks, known as fake news.

Finally, the skills presented and developed with the engagement of the groups in the production of memes unfold in the collective understanding about the need to think about teaching practices, so that it is possible to bring to classrooms new digital or textual genres such as the multisemiotic ones, thus contributing to the constitution of a quality and more effective teaching. Therefore, it is necessary to think of activities that stimulate the development of students' critical sense and reflection for the understanding of texts/genres that circulate in society, that is, that are meaningful to students and that make sense.

\section{References}

Angrosino, M. V. Ethnography and participant observation.

Blackmore, S. The Meme Machine. Oxford University Press.

Blaszkowski, D. A. A. M. Digital genres: considerations about a meaningful teaching practice in the context of elementary school. 2019.123 f. Dissertation Professional Master in Education and New Technologies, 2019. <https://repositorio.uninter.com/handle/1/447>.

Cavalcanti, D. P. R., \& Lepre, R. M. Using memes as a pedagogical resource in history classes. CIET: EnPED, 2018.

Brazil, Ministry of Education. National Curricular Parameters for Elementary Education. Brasília, 1997.

Brasil. Ministry of Education. Base Nacional Comum Curricular. Brasília, 2018. <http://basenacionalcomum.mec.gov.br/images/BNCC_20dez_site.pdf>. A

EEEF Bom Jardim - State Elementary School. Escol.as: <https://www.escol.as/14849-bom-jardim>.

Ferreira, H. M., et al. (2019). Memes in the classroom: possibilities for reading multiple semiotics. Periphery, 11, 114-139.

Fiorin, J. L. (2017). Tense semiotics. New paths of linguistics. Context.

Lara, M. T. A. (2017). The presence of memes in online mother tongue classes: considerations on multilearning and reading practices of verbo-visual utterances. Miguilim-Revista Eletrônica do Netlli, Crato, 6(1), 05-23.

Marcuschi, L. A., \& Xavier, A. C. Hipertext E Gêneros Digitais Novas formas de construção de sentido. Lucena

Medeiros, V. A. The fourth monkey is born. Blogger Technology, 2020.: <https://vangemedeiros.blogspot.com/2020/07/nasce-o-quarto-macaquinho.html>.

Ribeiro, A. E. Technology and semiotic power: writing, today. Free text: language and technology, 8, 112-123.

Ribeiro, A. E. Writing, today: word, image and digital technologies in education. Parábola.

Ribeiro, M. H., \& Freitas, M. T. A. Digital literacy: a contemporary challenge for education. Education \& Tecnology, 6.

Salek, S. The true meanings of some of the most popular emojis. BBC News, 2016. <https://www.bbc.com/portuguese/noticias/2016/04/160418 _emojis_significados_fn\#: :text=Generally\%20the\%20s\%20C3\%ADmbols\%20of\%20mackeys,promise $\% 20$ of $\% 20$ saving $\% 20 \mathrm{a} \% 20$ secret.>.

Semis, L. Media literacy guide: how to identify and combat misinformation.

Nova escola, 2018. <https://novaescola.org.br/conteudo/12307/guia-de-letramento-midiatico-o-que-e-como-aplicar-e-identificar-desinformacao>.

Sena, C da C. From teaching normative grammar to linguistic/semiotic analysis. 2018. $31 \mathrm{f}$. Coursework (Specialization in Teaching Portuguese Language and Literature) - Universidade Tecnológica Federal do Paraná.

Soares, M. What is literacy and literacy. Soares, M. Literacy: a theme in three genres. Autêntica, 1998.

Vygotsky, L. S. Problems of method. In: The Social Formation of Mind. Translation José Cipolla Neto, Luis S. M. Barreto, Solange C. Afeche. 3. Martins Fontes. 